\title{
A New Report on Oidiodendron flavum Isolated from Field Soil in Korea
}

\author{
Mahesh Adhikari', Sangwoo Kim', Dil Raj Yadav', Anam Giridhar Babu', Changmu Kim², Hyang Burm Lee \\ and Youn Su Lee ${ }^{1 *}$
}

${ }^{1}$ Division of Bioresource Sciences, Kangwon National University, Chuncheon 200-701, Korea

${ }^{2}$ Microorganisms Resources Division, National Institute of Biological Resources, Incheon 404-708, Korea

${ }^{3}$ Division of Applied Bioscience and Biotechnology, Chonnam National University, Gwangju 500-757, Korea

\begin{abstract}
Oidiodendron flavum KNU13-6 was isolated for the first time from field soil in Korea and identified based on the internal transcribed spacer region (ITS) of rDNA and morphological characteristics. Based on phylogenetic analysis of ITS and morphological characteristics, the species has not been previously reported in Korea.
\end{abstract}

KEYWORDS : Molecular identification, Morphology, Oidiodendron flavum, Proteolytic activity

Oidiodendron flavum Svilv., Lent. Bakto. belongs to genus Oidiodendron, a cosmopolitian genus whose members can usually be found in a wide range of habitats, including soils, different cellulose substrates (litter, wood pulp, bark, mosses, paper), and occasionally from lichens or from air [1]. Some Oidiodendron species have been reported as ericoid mycorrhizal fungi [2]. Plants in the Ericaceae have a distinctive ericoid mycorrhizal association, which plays important roles in plant growth, nutrient uptake, and soil mineralization [5]. The ability of some ericoid mycorrhizal fungi (Oidiodendron maius) to dissolve $\mathrm{Zn}$ oxide has been reported [6]. In addition, ericoid mycorrhizal fungus, Oidiodendron cf. truncatum have medical value as novel antifungal agent producers used in treatment of life-threatening fungal infections in immunocompromised hosts such as human immunodeficiency virus (HIV) infected persons and cancer patients [7]. Among the species of Oidiodendron, O. flavum is a

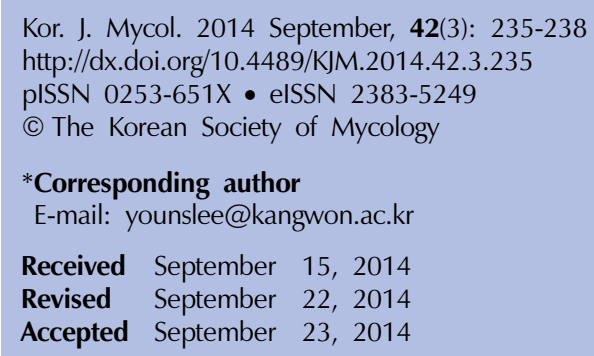

@This is an Open Access article distributed under the terms of the Creative Commons Attribution Non-Commercial License (http:// creativecommons.org/licenses/by-nc/3.0/) which permits unrestricted non-commercial use, distribution, and reproduction in any medium, provided the original work is properly cited. thermophillic fungus with the capacity for production of thrombolytic agents utilized in treatment of thrombosis $[8,9]$. The fibrinolytic enzyme obtained from thermophillus fungus O. flavum, exhibits a profound fibrinolytic activity and also exhibits relatively high $\mathrm{pH}$ and temperature stabilities [10]. Tahany et al., [8] also reported that a O. flavum released maximum amounts of either ammonia, peptides, or total soluble nitrogen. Thus, there has been considerable recent interst of mycologists in working with O. flavum.

During the studies of fungal diversity in agricultural soils in Korea, a species of Oidiodendron was discoverd that was not previously reported in Korea. Based on morphological and molecular characteristics, this species was identified as O. flavum.

Collection of soil samples and fungal isolation. Soil samples were collected from different locatoins in Taebaek city, Korea in 2013. Soil from (0-15) depth, air dried and stored in plastic bags at $4^{\circ} \mathrm{C}$ until used. The fungi were isolated by conventional dilution and supplemented with $100 \mu \mathrm{g}$ chloramphenicol per $\mathrm{mL}$ potato dextrose agar (PDA; Difco Laboratories, Detroit, USA) and grown for $7 \mathrm{~d}$ at $28^{\circ} \mathrm{C}$ until the growth of colonies was observed.

ITS sequencing analysis. Genomic DNA of the strain was extracted using the DNeasy Plant Mini Kit (Qiagen, Hilden, Germany) following the manufacturer's instructions. The ITS regions, including the $5.8 \mathrm{~S}$ were amplified with the primers ITS and ITS4 [11] The amplified PCR product was purified using a QIA quick PCR purification Kit (Qiagen, Valencia, CA, USA) following the manufac- 
Table 1. Morphological characteristics of Oidiodendron flavum isolated in this study

\begin{tabular}{|c|c|c|c|}
\hline Characteristics & & O. flavum isolated in this study & O. flavum ${ }^{\mathrm{a}}$ \\
\hline \multirow[t]{2}{*}{ Colony } & Texture & $\begin{array}{l}\text { Colonies on PDA are limited in growth, } \\
\text { non-aerial and radially sulcate }\end{array}$ & $\begin{array}{c}\text { Colonies on PDA are limited in growth, } \\
\text { non-aerial and partially ropy }\end{array}$ \\
\hline & Color & Pale brown and cream & Yellowish brown \\
\hline \multirow[t]{2}{*}{ Conidiophores } & & $\begin{array}{l}\text { Conidiophores hyaline, branched } \\
\text { oppositely and verticillately in the } \\
\text { median, bearing conidia apically and }\end{array}$ & $\begin{array}{l}\text { Conidiophores brown, erect branched alternately, } \\
\text { oppositely or rarely verticillately in the median, } \\
\text { bearing conidia apically, apparently dendroid like } \\
\text { denticulate after detachment of conidia and }\end{array}$ \\
\hline & Size $(\mu \mathrm{m})$ & $60.0 \sim 90.0$ & $62.5 \sim 87.5$ \\
\hline \multirow[t]{2}{*}{ Conidia } & $\begin{array}{l}\text { Shape and } \\
\text { position }\end{array}$ & $\begin{array}{l}\text { Hyaline, irregular, one celled. Conidial } \\
\text { chains straight and readily detached }\end{array}$ & $\begin{array}{l}\text { Hyaline, globose or irregular, occasionally } \\
\text { with a fragment of conidiophores, } \\
\text { one celled and readily detached }\end{array}$ \\
\hline & Size ( $\mu \mathrm{m}$ in diam.) & $2.0 \sim 3.8 \times 2.5 \sim 3.5$ & $1.8 \sim 3.8$ \\
\hline
\end{tabular}

${ }^{a}$ Source of description (Barron, 1962; Watanabe et al., 1986a).

turer's recommendations. The PCR product was sequenced using an ABI Prism 3730 DNA analyzer (Applied Biosystems, Foster city, CA, USA). The sequence was compared with reference ITS1-ITS4 rDNA sequences in GenBank using BLAST analysis (http://www.ncbi.nlm. nihgob/blast). The sequences of closely related strains were aligned using the MultAlin program. The DNA sequences were analyzed for phylogenetic relationship using Molecular Evolutionary Genetics Analysis (MEGA 5) software [12] The sequence of present isolate, KNU 13-6, was compared with the sequences in GenBank using Basic Local Alignment Search Tool (BLAST). NeighborJoining tree was constructed using Kimmura 2-parameter substitution model bootstrap analysis was performed with 1,000 replications in order to determine the support for each clade. ITS regions of the KNU13-6 were 100\% identical to the culture collection of O. flavum (accession no. KJ921607) [13] (Fig. 1). Phylogenetic tree of the ITS regions of the isolate (KNU13-6) was identical to $O$. flavum with $97 \%$ bootstrap value support (Fig. 1). The results strongly suggest that the isolate is O. flavum. Consequently, the nucleotide sequence of the isolate reported here has been registerd in the NCBI GenBank (Accession no. KJ921607).

Morphological characteristics and identification. Morphological features were observed on potato dextrose agar

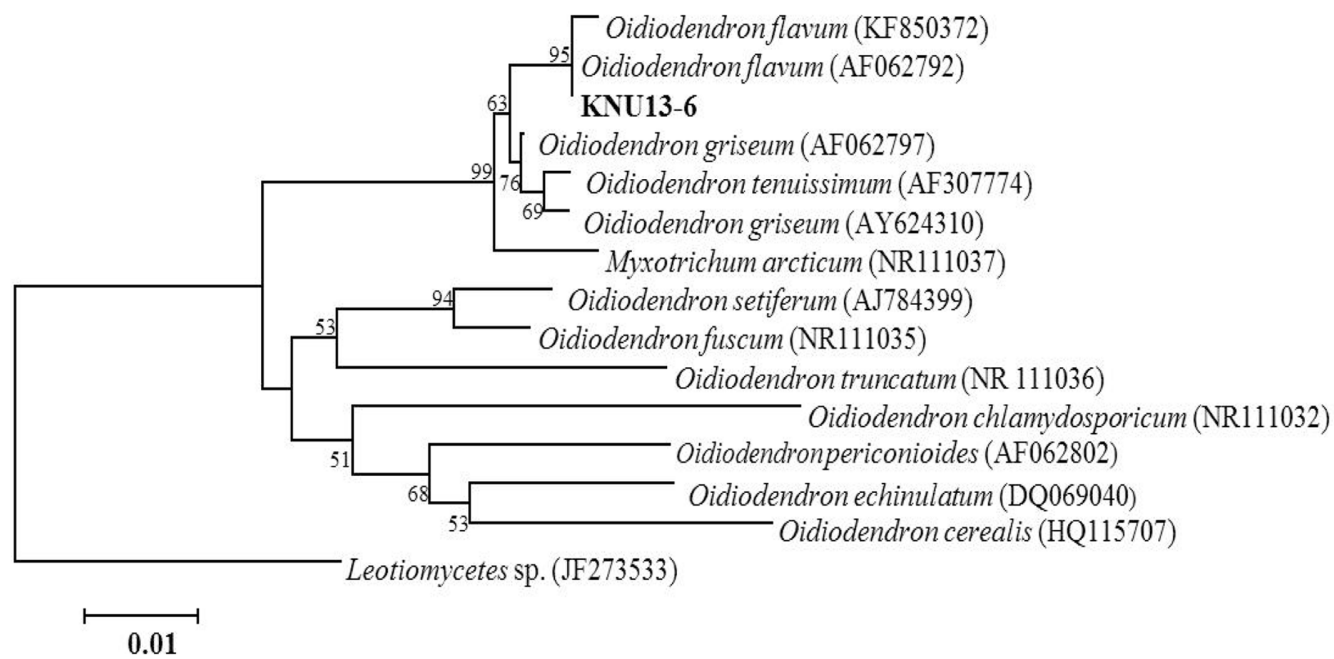

Fig. 1. Neighbor-joining phylogenetic analysis of Oidiodendron flavum KNU13-6 partial 18S-ITS1-5.8S-ITS2-28S rDNA region sequence obtained from crop field soil in Korea. The sequence obtained in the study is shown in boldface. Numerical values $(>50)$ on branches are the bootstrap values as percentage of bootstrap replication from 1,000 replicate analysis. Leotiomycetes sp. (JF273533) was used as the outgroup. 
(PDA) by doing three point inoculations in $9 \mathrm{~cm}$ petri plates which were incubated in the dark at $28^{\circ} \mathrm{C}$ for 7 days. The morphological characteristics were identified with the aid of differential interference contrast microscopy. Photomicrographs were taken with a Kodak14n digital camera attached to the microscope. Slide material was mounted in water and sometimes with aniline blue staining. Colonies on PDA were slow growing, pale brown, cream, attaining $20 \sim 30 \mathrm{~mm}$ after growing for 10 days at $28^{\circ} \mathrm{C}$. Conidiophores were hyaline, branched alternately, oppositely or rarely verticillately in the medium (Fig. 2). Conidiophores arising from the mycelial substrate, 60-90 $\mu \mathrm{m}$ tall from base to branching site. Conidia 1.8-3.8 $\mu \mathrm{m}$ in diameter. Conidia arthrospores, hyaline, globose or irregular, occasionally with a fragment of conidiophore, one celled readily detached (Fig. 2). Conidia were hyaline, irregular, 2-3.8 $\times$ 2.5-3.5 $\mu \mathrm{m}$ in diameter. Morphological characteristics of the isolate agreed with the description of O. flavum $[9,15]$. Based on the phylogenetic analysis and morphological characteristics of strain KNU

\section{3-6 was O. flavum.}

In conclusion, we identified and described Oidiodendron flavum KNU13-6 as an unrecorded species in Korea. The species of Oidiodendron have the ability to produce phytohormones, solubilize insoluble phosphate and convert complex organic substances to simple forms and fibrinolytic enzymes. Thus, in the future, further inverstigation in this respect would be worthwhile.

\section{ACKNOWLEDGEMENTS}

This study was supported by the National Institute of Biological Resources (NBIR), Ministry of Environment, Republic of Korea, for the project on survey and excavation of Korean indigenous fungal species.

\section{REFERENCES}

1. Domsch KH, Gams W, Anderson TH. Common wealth of soil fungi. volume 1, Academic Press, London. 1980; pp. 859.

2. Couture M, Fortin JA, Dalpe Y. Oidodendron griseum Robak:
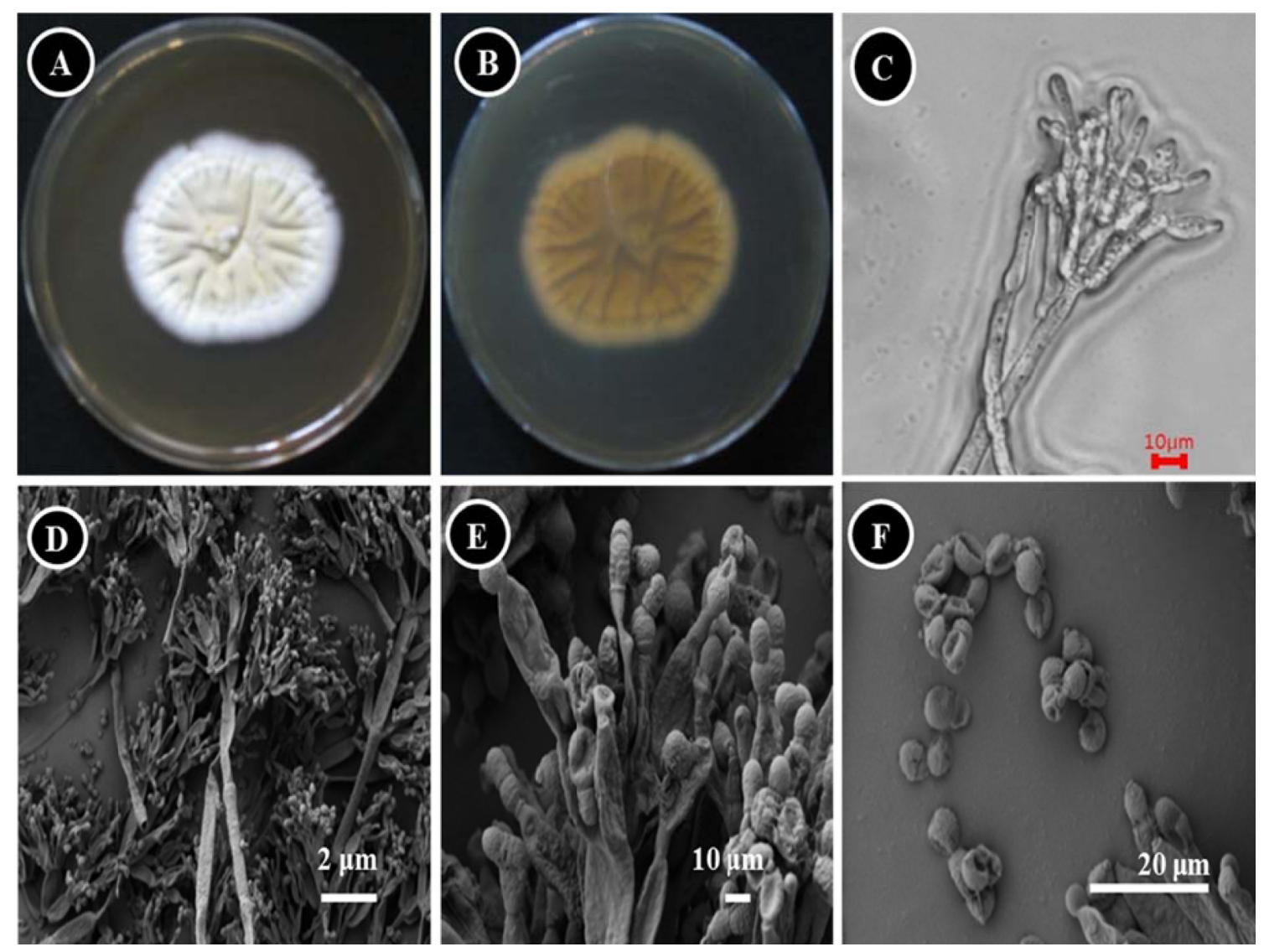

Fig. 2. Morphological characterization of Oidiodendron flavum KNU13-6 observed using a compound microscope and scanning electron microscope (SEM). A, Colony in front; B, Colony in reverse; C, Conidiophores (Compound miscroscope image; bar = $10 \mu \mathrm{m}$ ). D and E, Conidiophores and conidia (SEM micrograph; bar $=2$ and $10 \mu \mathrm{m}$ ), and F, Conidia (SEM micrograph; bar = $20 \mu \mathrm{m})$. 
an endophyte ofericoid mycorrhiza in Vaccinum spp. New Phytol 1983;98:375-80.

3. Dalpe Y. Ericoid mycorrhizal fungi in the Myxotrichaceae and Gymnoasceae. New Phytol 1989;113:523-7.

4. Lacourt L, Girlanda M., Perotto S, Del pero M, Zuconn D, Luppi AM.. Nuclear ribosomal sequence analysis of Oidodendron: towards a redefinition of ecologically relevant species. New Phytol 2001;149:565-6.

5. Smith SE, Read J. Mycorrhizal symbiosis. 3rd ed. London: AcademicPress. p. 800.

6. Martino E, Perotto S, Parsons R, Gadd GM.. Solubilization of insoluble inorganic zinc compounds by ericoid mycorrhizal fungi derived from heavy metal polluted sites. Soil Biol Biochem 2003;35:133-41.

7. Hosoe T, Nozawa K, Lumley TC., Currah RS., Fukushima K, Takizawa K,Miyaji M, K Kawai. Tetranorditerpene Lactones, Potent Antifungal Antibiotics for Human Pathogenic Yeasts, from a Unique Species of Oidiodendron. Chem Pharm Bull 1999;47:1591-7.

8. Tahany MAA, Abdel-Aziz MS, Mohamd IAA, Nagwa AHT. Fibrinolytic activity of some fungi isolated from delf-heated composted fertilizer. Botanical society Japan 1990;103:313-24.
9. Von Szilvinyi A. Mikrobiologische Boden untersuchungen im Lunzer Bebiet. Zentralblatt für Bakteriologie Abteilung II. Bakteriologie Abteilung II. Bakteriologie Abteilung II 1941; 103:133-89.

10. Tharwat NA. Purification and Biochemical characterization of fibrinolytic enzyme produced by thermophillic fungus Oidodendron flavum. Biotechnology 2006;160-5.

11. Tamura K, Stecher G, Peterson D, Filipski A, Kumar S. MEGA5: Molecular evolutionary genetic analysis version 6.0 Mol Biol Evol 2013;30:2725-9.

12. Kimmura M. A simple method for estimating evolutionary nucleotide sequences. J Mol Evol 1980;16:111-20.

13. Robeson MS II, Cosrello EK, Freeman KR, Whiting J, Adams B, Martin AP, Schmidt SK. Environmental DNA sequencing primers for eutardiagrades and bdelloid rotifers. J BMC Ecol 2009;9:25.

14. Barron GL. New species and new records of Oidodendron. Can J Bot 1962;48:589.

15. Watanabe T, Uematsu S, Sato Y. Fungus isolates from Japanese black and red pine seeds with some taxonomical notes. Bull For For Prod Res Inst 1986;336:1-18. 